\title{
CO NOWEGO W NEUROLOGII/WHAT'S NEW IN NEUROLOGY
}

\section{Stężenie markera stanu zapalnego YKL-40 we krwi a ryzyko udaru mózgu}

Kjaergaard AD, et al. Elevated plasma YKL-40 levels and ischemic stroke in the general population. Ann Neurol 2010; 68: 672-680.

Miażdżyca spowodowana jest odkładaniem się lipoprotein w błonie wewnętrznej naczyń. We wczesnej fazie miażdżycy dochodzi do naciekania ściany naczyń przez monocyły, które później ulegaia przekształceniu w obładowane łłuszczem makrofagi. YKL-40 to glikoproteina produkowana miejscowo przez obładowane łtuszczem makrofagi. Autorzy pracy przeprowadzili prospektywne badanie populacyjne oceniajace zwiazek pomiędzy stężeniem YKL-40 we krwi a ryzykiem rozwoju chorób układu krążenia. W badaniu wzięło udział 8899 osób (57\% kobiet) w wieku 21-93 lat. W trakcie 18-letniego okresu obserwacji zawał mózgu wystapił u 615, a zawał serca u 673 osób. Diagnozę choroby niedokrwiennej serca postawiono u 1475 osób, natomiast rozpoznanie niedokrwiennej choroby naczyniowej mózgu (ICD-10: 1-63-I64, G45) ustalono u 769 osób. Badanych podzielono na 4 grupy w zależności od percentyla stężeń YKL-40 we krwi (grupa I: 0-33\%, grupa II: 34-66\%, grupa III: 67-90\%, grupa IV: 91-100\%). Po uwzględnieniu innych czynników ryzyka, w tym wieku, płci, cukrzycy, nadciśnienia tętniczego, migotania przedsionków, palenia papierosów, ilości spożywanego alkoholu, stężenia cholesterolu oraz białka C-reaktywnego, ryzyko względne wystapienia zawału mózgu wynosiło 1,2 $(95 \% \mathrm{Cl}: 0,9-1,6)$ u osób w grupie II, 1,8 $(95 \% \mathrm{Cl}: 1,3-2,4)$ w grupie III i 2,3 (95\% Cl: 1,5-3,3) w grupie IV w porównaniu z grupq I. Ryzyko względne wystapienia niedokrwiennej choroby naczyniowej mózgu wynosiło $1,2(95 \% \mathrm{Cl}$ : 0,9-1,5) w grupie II, 1,6 (95\% Cl: 1,2-2,0) w grupie III i 2,2 (95\% Cl: 1,6-3,2) w grupie IV. Ryzyko względne wystąpienia zawału serca nie różniło się znacząco pomiędzy grupami. Ryzyko względne wystapienia choroby niedokrwiennej serca wynosiło 1,0 (95\% Cl: 0,8-1,2) w grupie II, 1,2 (95\% Cl: 1,0-1,5) w grupie III i 1,3 $(95 \% \mathrm{Cl}: 1,0-1,6)$ w grupie IV. Podwojenie stężenia YKL-40 we krwi wiqzało się ze zwiększeniem ryzyka wystapienia zawału mózgu o 20\%, niedokrwiennej choroby naczyń mózgowych o 16\%, zawału serca o $3 \%$, a choroby niedokrwiennej serca ○ $7 \%$. Wyniki badania wskazuja, że zwiększone stężenie YKL-40 we krwi wiq̨że się ze zwiększonym ryzykiem wystapienia niedokrwienia mózgu.

\section{Wpływ zespołu metabolicznego na funkcje poznawcze}

Cavalieri $M$, et al. Metabolic syndrome, brain magnetic resonance imaging, and cognition. Diabetes Care 2010; 33: 2489-2495.

Zespół metaboliczny to klaster sercowo-naczyniowych czynników ryzyka, do których należą: podwyższone ciśnienie tętnicze, otyłość typu brzusznego, promiażdżycowe zaburzenia lipidowe, nietolerancja glukozy i insulinooporność. Autorzy pracy oceniali zwiq̨zek pomiędzy zespołem metabolicznym a zaburzeniami funkcii poznawczych. W badaniu wzięło udział 819 osób wybranych z populacji ogólnej (średnia wieku: 65 lat). Zespół metaboliczny zdiagnozowano u 232 osób (28,3\%). U wszystkich osób wykonano badanie RM mózgu oraz przeprowadzono badanie neuropsychologiczne oceniające pamięć, zdolność uczenia się, funkcje psychomotoryczne i wykonawcze. Osoby z zespołem metabolicznym nie różniły się istotnie od osób bez zespołu metabolicznego pod względem ilości zawałów lakunarnych, niemych klinicznie ognisk niedokrwienia, objętości mózgu oraz nasilenia zmian w istocie białej mózgu. Osoby z zespołem metabolicznym uzyskały znacząco gorsze wyniki w testach oceniajacych pamięć i funkcje wykonawcze. Zwiq̨zek pomiędzy obecnościq zespołu metabolicznego a zaburzeniami funkcji poznawczych był widoczny u mężczyzn, ale nie u kobiet. Zaburzenia funkcji poznawczych u mężczyzn ze zdiagnozowanym zespołem metabolicznym były bardziej nasilone $\mathrm{u}$ osób ze zwiększonym stężeniem białka C-reakływnego we krwi. Wyniki badania wskazuja, że obecność zespołu metabolicznego u mężczyzn wiq̨że się z pogorszeniem funkcji poznawczych. Proces zapalny, a nie obecność zmian niedokrwiennych w mózgu może predysponować do wystapienia zaburzeń poznawczych w tej grupie chorych.

\section{Trójpierścieniowe leki przeciwdepresyjne w leczeniu bólów głowy}

Jackson JL, et al. Tricyclic antidepressants and headaches: systematic review and meta-analysis. BMJ 2010; 341: c5222.

Autorzy pracy dokonali systematycznego przeglądu i metaanalizy opublikowanych badań dotyczących stosowania tróipierścieniowych leków przeciwdepresyjnych (TLPD) w leczeniu bólów głowy. Do ostatecznej analizy zakwalifikowano 37 badań z randomizacja, w kłórych TLPD podawane były w monoterapii przez 
co najmniej 4 tygodnie. Przed włączeniem leczenia TLPD pacjenci odczuwali migrenowy ból głowy średnio 4,7 razy w miesiącu, a ból głowy typu napięciowego - 16,9 razy w miesiącu. Po leczeniu liczba migrenowych bólów głowy zmniejszyła się średnio o 1,4, a bólów głowy typu napięciowego o 6,9 w ciągu miesiq̨ca. Korzystny efekt podawania TLPD rósł wraz z czasem stosowania leku. Pacjenci zażywajacy TLPD mieli większą szansę na zmniejszenie o co najmniej 50\% nasilenia bólu głowy, zarówno migrenowego (RR: 1,8; 95\% Cl: 1,24-2,62), jak i bólu głowy typu napięciowego (RR: 1,41; 95\% Cl: 1,02-1,89) niż pacjenci otrzymujący placebo. Leki te okazały się lepsze niż inhibitory zwrotnego wychwytu serotoniny w zmniejszaniu nasilenia bólu głowy. Częściej niż placebo (RR: 1,53; 95\% Cl: 1,11-2,12) i inhibitory zwrotnego wychwytu serotoniny (RR: 2,22; 95\% Cl: 1,52-3,32) były przyczyną wystąpienia objawów niepożądanych. Do najczęstszych objawów niepożądanych należały: suchość w jamie ustnej, senność i przyrost masy ciała. Wyniki analizy potwierdzaja przydatność TLPD w leczeniu migreny i bólu głowy typu napięciowego.

\section{Stężenie oligomerów $\alpha$-synukleiny w płynie mózgowo-rdzeniowym jako marker choroby Parkinsona}

Tokuda T, et al. Detection of elevated levels of $\alpha$-synuclein oligomers in CSF from patients with Parkinson disease. Neurology 2010; 75: 1766-1772.

Mutacje genu dla $\alpha$-synukleiny są przyczyna rodzinnej postaci choroby Parkinsona o wczesnym początku. Złogi $\alpha$-synukleiny są głównym biochemicznym składnikiem ciał Lewy'ego. Autorzy pracy oceniali stężenie $\alpha$-synukleiny i jej oligomerów w płynie mózgowo-rdzeniowym u 32 osób z chorobą Parkinsona. Grupę kontrolną stanowiło 16 osób bez chorób neurologicznych oraz 12 osób z innymi chorobami neurologicznymi (zawał mózgu, padaczka, mielopatia, polineuropatia, miopatia), dobranych pod kątem płci i wieku. Całkowite stężenie $\alpha$-synukleiny w płynie mózgowo-rdzeniowym było mniejsze u osób z chorobą Parkinsona niż w grupie kontrolnei (średnie stężenie: 20,98 $\pm 0,76$ w porównaniu z 24,40 $\pm 1,17 \mathrm{ng} / \mathrm{ml} ; P=0,04)$. Stężenie oligomerów $\alpha$-synukleiny było większe u osób z chorobą Parkinsona (średnie stężenie: $19791 \pm$ 2458 jednostek) w porównaniu z osobami bez chorób neurologicznych (średnie stężenie: $10796 \pm 1715$ jednostek, $P<0,05)$ oraz osobami $z$ innymi chorobami neurologicznymi (średnie stężenie: $8096 \pm 596$ jednostek, $P<0,01)$. Także stosunek stężenia oligomerów $\alpha$-synukleiny do całkowitego stężenia $\alpha$-synukleiny był większy u osób z chorobą Parkinsona $(12,9 \pm 1,08)$ w porównaniu z osobami bez chorób neurologicznych $(5,32 \pm 0,85 ; P<0,001)$ oraz osobami z innymi chorobami neurologicznymi $(3,68 \pm$ $0,36 ; P<0,001)$. Stężenie oligomerów $\alpha$-synukleiny w płynie mózgowo-rdzeniowym nie korelowało z wiekiem pacjentów, stopniem zaawansowania choroby ocenianym w skali Hoehn-Yahra oraz czasem trwania choroby. Stężenie oligomerów $\alpha$-synukleiny $>9950$ jednostek różnicowało osoby z choroba Parkinsona od osób bez choroby Parkinsona z czułościa 75\% i swoistościa 87,5\%. Stosunek oligomerów do całkowitego stężenia $\alpha$-synukleiny $>6,165 \%$ różnicował osoby $z$ choroba Parkinsona od osób bez choroby Parkinsona z czułością 89,3\% i swoistością 90,6\%. W kolejnym badaniu wykazano, że stężenie oligomerów $\alpha$-synukleiny było znamiennie większe u osób z choroba Parkinsona niż u osób z postępujacym porażeniem nadjądrowym i z choroba Alzheimera. Wyniki badania sugeruja, że stężenie oligomerów $\alpha$-synukleiny w płynie mózgowo-rdzeniowym może służyć jako marker choroby Parkinsona.

\section{Spektroskopia rezonansu magnetycznego w chorobie Huntingtona}

Sturrock A, et al. Magnetic resonance spectroscopy biomarkers in premanifest and early Huntington disease. Neurology 2010; 75: 1702-1710.

Spektroskopia rezonansu magnetycznego pozwala na bezinwazyjny, przyżyciowy pomiar wybranych metabolitów w mózgu. Autorzy pracy przeprowadzili badanie spektroskopii rezonansu magnetycznego u 30 pacjentów we wczesnej fazie choroby Huntingtona, 25 osób w przedklinicznej fazie choroby Huntingtona oraz u 30 osób z grupy kontrolnej. Przedkliniczną fazę choroby Huntingtona definiowano jako obecność co najmniej 40 powtórzeń trójki nukleotydów CAG w genie HTT oraz brak znaczacego deficytu ruchowego. Oznaczenie wybranych metabolitów przeprowadzono za pomoca 3-teslowego aparatu RM w obrębie pojedynczego woksela zlokalizowanego w lewej skorupie mózgu. Oznaczono spektra następujących metabolitów: N-acetyloasparaginianu (NAA) i N-acetyloaspartyloglutaminaniu (NAAG), których suma (tNAA) jest markerem integralności neuronów; kreatyny $(\mathrm{Cr})$ i fosfokreatyny (PCr), których suma ( $+\mathrm{Cr}$ ) jest markerem glikozy i statusu energetycznego mózgu; glicerofosfo- 
choliny (GPC) i fosfocholiny (PC), których suma (†Cho) jest markerem obrotu błonami komórkowymi neuronów; kwasu glutaminowego (Glu), będącego głównym pobudzającym neuroprzekaźnikiem układu nerwowego, oraz mioinozytolu $(\mathrm{ml})$, będacego markerem astrocyłów. Stężenie tNAA było o 15\% mniejsze u pacjentów we wczesnej fazie choroby Huntingtona niż w grupie kontrolnej $(P<0,001)$. Stężenie NAA było - $8 \%$ mniejsze u pacjentów w przedklinicznej fazie choroby Huntingtona oraz o 17\% mniejsze u pacjentów we wczesnej fazie choroby Huntingtona w porównaniu z grupa kontrolna $(P<0,05)$. Stężenie $\mathrm{ml}$ było o 50\% większe u pacjentów we wczesnej fazie choroby Huntingtona niż u osób w przedklinicznej fazie choroby $(P<0,01)$. U pacjentów we wczesnej fazie choroby Huntingtona stężenie $\mathrm{ml}$ korelowało ze stopniem deficytu ruchowego ocenianego w Unified Huntington's Disease Rating Scale ( $R 2=0,23 ; P<0,05)$. Wyniki badania sugeruja, że zmniejszone stężenie tNAA i zwiększone stężenie $\mathrm{ml}$ w obrębie skorupy moga służyć jako biomarkery choroby Huntingtona.

\section{Przewlekłe limfocytarne zapalenie mostu reagujq̨ce na leczenie kortykosteroidami}

Pittock SJ, et al. Chronic lymphocytic inflammation with pontine perivascular enhancement responsive to steroids (CLIPPERS). Brain 2010; 133: 2626-2634.

Autorzy pracy przedstawili obraz kliniczny nowej jednostki chorobowej o podłożu immunologicznym - przewlekłego limfocytarnego zapalenia mostu, reagujacego na leczenie kortykosteroidami. U 8 pacjentów (w tym 5 kobiet) o medianie wieku 45,5 roku (zakres: 16-86 lat) stwierdzono oczoplas i ataksie chodu o podostrym początku. Wśród innych objawów obserwowano dyzartrię, zaburzenia czucia w obrębie twarzy i czaszki, rzadziej - zespół rzekomoopuszkowy, szumy uszne, drżenie oraz objawy wskazujące na uszkodzenie rdzenia kręgowego. Badanie RM mózgu wykazało obecność punktowych (o maksymalnej średnicy $9 \mathrm{~mm}$ ) i liniowych zmian wzmacniających się po podaniu kontrastu zlokalizowanych $w$ moście i przechodzących do rdzenia przedłużonego, śródmózgowia, iąder podstawy, móżdżku i rdzenia kręgowego. W badaniu płynu mózgowo-rdzeniowego u 4 pacjentów stwierdzono niewielkie zwiększenie stężenia białka (47-65 mg/dl), a u 3 pacjentów wykryło obecność prążków oligoklonalnych. Biopsię mózgu wykonano u 4 pacjentów, pobierajac fragment móżdżku lub mostu. Badanie neuropatologiczne wykazało obecność okołonaczyniowego nacieku limfocyłarnego złożonego głównie z limfocytów T. Ponadto obserwowano obecność aktywnych komórek mikrogleju. Nie stwierdzono zmian patologicznych $w$ zakresie mieliny. Poczq̨tkowo u wszystkich pacjentów obserwowano poprawę stanu klinicznego po włączeniu kortykosteroidów. Leczenie kortykosteroidami prowadziło również do zmniejszenia zmian patologicznych widocznych w badaniu RM. Wszyscy pacjenci podczas trwajacej średnio 22 miesiące obserwacii wymagali przewlekłego podawania kortykosteroidów - próby odstawienia leku powodowały nawrót dolegliwości.

\section{Posoznica a zaburzenia funkcii poznawcych}

Iwashyna TJ, et al. Long-term cognitive impairment and functional disability among survivors of severe sepsis. JAMA 2010; 304: 1787-1794.

Autorzy pracy oceniali, czy przebycie ciężkiej posocznicy zwiększa ryzyko pogorszenia funkcji poznawczych i sprawności. Pacjentów do badania rekrutowano spośród osób uczestniczq̨cych w prospektywnym badaniu populacyinym The Health and Retirement Study. W przypadku osób zakwalifikowanych do badania dostępne były informacje na temat funkcii poznawczych oraz stopnia sprawności przed zachorowaniem na posocznicę. Do ostatecznej analizy włączono dane 516 osób, kłóre przeżyły posocznicę, i 4517 osób, które były hospitalizowane z powodów innych niż posocznica. Minimalny okres obserwacji po wypisie ze szpitala wynosił rok. Średnia wieku pacjentów w momencie hospitalizacji wynosiła 76,9 roku. W odróżnieniu od pacjentów hospitalizowanych z powodów innych niż posocznica, u pacjentów, którzy przebyli posocznicę, występowało zwiększone ryzyko umiarkowanego lub ciężkiego pogorszenia funkcji poznawczych (OR: 3,34; 95\% Cl: 1,53-7,25) oraz upośledzenia sprawności niezbędnej w wykonywaniu codziennych czynności (OR: 1,57; 95\% Cl: 0,99$2,15)$. Zaburzenia funkcii poznawczych i pogorszenie sprawności utrzymywały się przez co najmniej 8 lat obserwacji. Wyniki badania wskazuja, że przebycie ciężkiej posocznicy predysponuje do wystąpienia zaburzeń funkcji poznawczych i zwiększa ryzyko niepełnosprawności. 


\section{Wpływ nadciśnienia tętniczego i palenia papierosów na wielkość tętniaków mózgu}

Etminan $\mathrm{N}$, et al. The impact of hypertension and nicotine on the size of rupture intracranial aneurysms. J Neurol Neurosurg Psychiatry 2010; 82: 4-7.

Autorzy pracy oceniali wpływ modyfikowalnych czynników ryzyka na wielkość pękniętych tętniaków mózgu. Analizie retrospektywnej poddano dane 373 pacjentów hospitalizowanych z powodu krwotoku podpaięczynówkowego z pękniętego tętniaka. Średnia wielkość tętniaków mierzona w badaniu angiograficznym $w$ badanej populacii wyniosła 6,86 $\pm 4,26 \mathrm{~mm}$. Naiwięcej $(53,9 \%)$ było tętniaków o wielkości 4-7 mm. Średnia wielkość tętniaków u osób, które chorowały na nadciśnienie i paliły papierosy $(5,47 \pm 3,22 ; 95 \%$ $\mathrm{Cl}: 4,71-6,24)$, była znacząco mniejsza niż u osób, które chorowały na nadciśnienie i nie paliły papierosów $(6,27 \pm 3,28 \mathrm{~mm}, 95 \% \mathrm{Cl}: 5,75-6,78)$, oraz osób, kłóre paliły papierosy, ale nie chorowały na nadciśnienie $(7,61 \pm 4,29 \mathrm{~mm}, 95 \% \mathrm{Cl}: 6,43-8,79)$, jak również osób bez wymienionych czynników ryzyka $(8,08 \pm 4,73 \mathrm{~mm}, 95 \% \mathrm{Cl}: 6,96-9,21)$. Wyniki badania sugeruja, że nadciśnienie tętnicze i palenie papierosów wpływaja destrukcyinie na ścianę tętniaków, prowadząc do ich wcześniejszego pękania.

\section{Prace polskich autorów}

\section{Przezskórne podawanie antygenów mieliny w leczeniu stwardnienia rozsianego}

Juryńczyk $M$, Walczak $A$, Jurewicz $A$, Jesionek-Kupnicka J, Szczepanik M, Selmaj K. Immune regulation of multiple sclerosis by transdermally applied myelin peptides. Ann Neurol 2010; 68: 593-601.

Badania doświadczalne prowadzone na zwierzęcych modelach stwardnienia rozsianego wykazały, że śródskórne podawanie białka zasadowego mieliny zapobiega wystapieniu rzutu choroby. Autorzy pracy przeprowadzili badanie oceniajace wpływ przezskórnego podawania antygenów mieliny na funkcje układu immunologicznego u chorych na stwardnienie rozsiane. W trakcie kolejnych 12 miesięcy 30 pacjentów z rzutowa postacia stwardnienia rozsianego otrzymywało poprzez naklejony na skórę plaster mieszaninę wybranych antygenów mieliny lub placebo. $U$ pacjentów otrzymujacych antygeny mieliny w miejscu przyklejenia plastra stwierdzono aktywację komórek dendryłycznych Langerhansa. Ponadto w węzłach chłonnych drenujących obszar skóry, do którego przyklejony był plaster, zaobserwowano obecność komórek dendrytycznych, odpowiedzialnych za prezentację antygenów limfocytom T. Badania in vitro wykazały, że w odpowiedzi na antygeny mieliny limfocyły T CD4+ wykazywały zmniejszoną proliferacię, a komórki jednojądrzaste krwi produkowały zwiększone ilości cytokiny antyzapalnej - interleukiny 10, oraz zmniejszone ilości cyłokiny pozapalnej - interferonu $\gamma$, i czynnika transformujacego wzrostu $\beta$. Wzrost syntezy interleukiny 10 przy jednoczesnym hamowaniu produkcii interferonu $\gamma$ i czynnika transformującego wzrostu $\beta$ sugeruje, że przezskórne podawanie antygenu spowodowało powstawanie we krwi regulatorowych limfocytów $T$, które moga mieć potencjalnie korzystne działanie na przebieg stwardnienia rozsianego. Wyniki badania stwarzaja nowe możliwości prowadzenia bardziej selektywnej, nastawionej na wybrane autoantygeny immunoterapii u chorych na stwardnienie rozsiane.

\section{Ostatnio opublikowane wytyczne}

Galvin R, Brathen G, Ivashynka A, Hillbom M, Tanasescu R, Leone MA; EFNS. EFNS guidelines for diagnosis, therapy and prevention of Wernicke encephalopathy. Eur J Neurol 2010; 17: 1408-1418.

Einhäupl K, Stam J, Bousser MG, De Bruijn SF, Ferro JM, Martinelli I, Masuhr F. EFNS guideline on the treatment of cerebral venous and sinus thrombosis in adult patients. Eur J Neurol 2010; 17: 1229-1235.

Opracował: dr med. Tomasz Dziedzic 